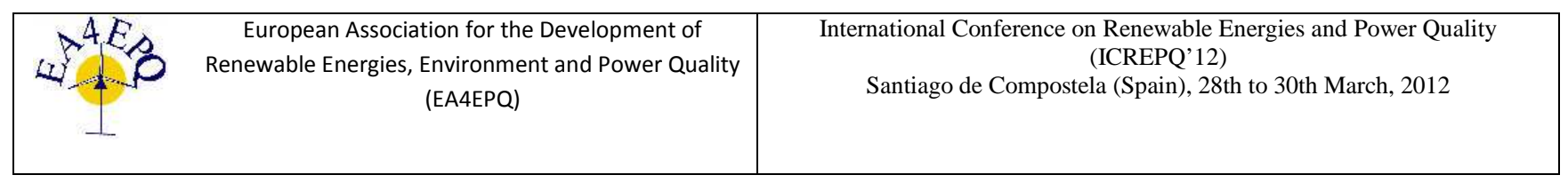

\title{
Obtaining microalgae biomass in a small scale reactor
}

\author{
Leonardo García ${ }^{1}$, Xavier Álvarez ${ }^{1}$, Kenya Bravo ${ }^{1}$, Juan Peralta $^{2}$, Alfredo Barriga ${ }^{2}$ \\ ${ }^{1}$ Laboratorio de Biotecnología \& Genética \\ Universidad de Guayaquil \\ Ave. Raúl Gómez Lince s/n y Ave. Juan Tanca Marengo, Guayaquil (Ecuador) \\ Phone: 04-2253117, e-mail: xalvarezec@gmail.com \\ ${ }^{2}$ Centro de Desarrollo Tecnológico Sustentable \\ Escuela Superior Politécnica del Litoral \\ Campus Prosperina, Km 30.5 vía Perimetral, Guayaquil (Ecuador) \\ Phone: 04-2269359, e-mail: abarriga@espol.edu.ec
}

\begin{abstract}
In order to industrialize massive production of microalgae with biotechnologically important traits, it is essential to reduce production costs through the design and evaluation of different culture media, which are reflected in the value of the final product. It is important to know and understand the dynamics of growth and behavior of the strain of interest, as well as the response to different environmental factors, in order to obtain an adequate and permanent production of biomass. Tetraselmis sp. is an ellipsoidal mobile, compressed alga with four flagella and the acute rear end with the anterior end of four lobes. It is green bright, $7 \mu \mathrm{m}$ in diameter and $10-16 \mu \mathrm{m}$ in length. It is a euryhaline species with ability to form spores, whose limits of tolerance to physical variables are very broad. It contains $49.22 \%$ protein, $10.60 \%$ lipid and $16.38 \%$ from carbohydrates. The microalgae Tetraselmis sp. was massively cultivated with Guillard media, and their biomass was harvested every $72 \mathrm{~h}$, we obtained an biomass average of $1.35 \mathrm{~g} / \mathrm{L} / \mathrm{d}$.
\end{abstract}

Key words: Biomass, microalgae, Guillard media.

\section{Introduction}

Global energy needs develop exponentially; however, the current reserves of fossil fuels are exhausted rapidly, which has led to explore new alternative and renewable emphasis has been placed on biotechnological development of microalgae for various areas from animal nutrition and cosmetics to the use of biomass for the production of biodiesel. The production of microalgae is complicated and is therefore necessary to use appropriate methodologies and enriched media, to achieve good density cultivation and reduce pollution [1; 2; 3]. Culture at large and medium scale of microalgae and the practical use of its biomass as a source of many products is very import; as an example of this, the use of the green algae Chlorella vulgaris, which can be used as a food supplement in aquaculture, to purify wastewaters in bioremediation [4].

Biodiesel is usually produced from oleaginous crops, such as rapeseed, soybean, sunflower and palm. However, the use of microalgae can be a suitable alternative feedstock for next generation biofuels because certain species contain high amounts of oil, which could be extracted, processed and refined into transportation fuels, using currently available technology; they have fast growth rate, permit the use of non-arable land and non-potable water, use far less water and do not displace food crops cultures; their production is not seasonal and they can be harvested daily [5].

\section{Cultivation of Tetraselmis $\mathbf{s p .}$}

Cultivation took place in sea water $(23 \%$ ) coming from town of Ballenita, filtered and enriched with nutrients from the Guillard $f / 2$ substrate [6], sterilized by autoclaving at $121^{\circ} \mathrm{C}$ $\mathrm{x} 1 \mathrm{~atm}$. for 15 minutes.

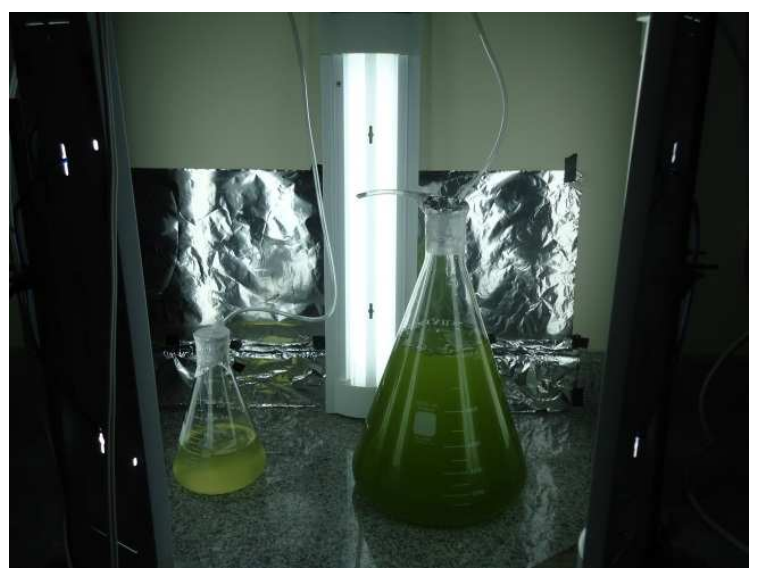

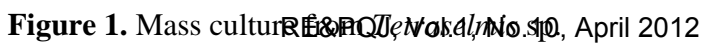


The culture was made in the laboratory of biotechnology and genetics, Faculty of Natural Sciences of the University of Guayaquil, $2^{\circ} 08^{\prime}$ 47.99 "S and 79 $55^{\circ} 03.69^{\prime \prime} \mathrm{W}$, in a location at 3 meters above sea level and with a process temperature of $22^{\circ} \mathrm{C}$. The cultivation was continued in flasks of $4000 \mathrm{~mL}$, harvesting 3000 $\mathrm{mL}$ every 72 hours. The culture was kept for a period of 15 days, replacing the harvested portion with an equivalent amount of fresh media; maintained with aeration $(920 \mathrm{cc} / \mathrm{min})$ and constant lighting of 1000 lux. Initial inoculum from Tetraselmis sp. had a concentration of 135000 cells/mL, every 24 hours cell count was performed in New Bauer chamber which was obtained to growth kinetics.

Table 1. Guillard's f/2 medium composition.

\begin{tabular}{lc}
\hline Trace elements stock solution & $\mathrm{L}$ \\
\hline $\mathrm{Na}_{2} \mathrm{EDTA}$ & $4.160 \mathrm{~g}$ \\
$\mathrm{FeCl}_{3} \cdot 6 \mathrm{H}_{2} \mathrm{O}$ & $3.150 \mathrm{~g}$ \\
$\mathrm{CuSO}_{4} \cdot 5 \mathrm{H}_{2} \mathrm{O}$ & $0.010 \mathrm{~g}$ \\
$\mathrm{ZnSO}_{4} \cdot 7 \mathrm{H}_{2} \mathrm{O}$ & $0.022 \mathrm{~g}$ \\
$\mathrm{CoCl}_{2} \cdot 6 \mathrm{H}_{2} \mathrm{O}$ & $0.010 \mathrm{~g}$ \\
$\mathrm{MnCl}_{2} \cdot 4 \mathrm{H}_{2} \mathrm{O}$ & $0.180 \mathrm{~g}$ \\
$\mathrm{Na}_{2} \mathrm{MoO}_{4} \cdot 2 \mathrm{H}_{2} \mathrm{O}$ & $0.006 \mathrm{~g}$ \\
Vitamin mix stock solution & $100 \mathrm{~mL}$ \\
Cyanocobalamin $\left(\right.$ Vitamin $\left.\mathrm{B}_{12}\right)$ & $0.0005 \mathrm{~g}$ \\
\hline ThiamineHCl $\left(\right.$ Vitamin $\left.\mathrm{B}_{1}\right)$ & $0.1000 \mathrm{~g}$ \\
Biotin & $0.0005 \mathrm{~g}$ \\
Media composition & \\
$\mathrm{NaNO}_{3}$ & $0.07500 \mathrm{~g}$ \\
$\mathrm{NaH}_{2} \mathrm{PO} \cdot 2 \mathrm{H}_{2} \mathrm{O}$ & $0.00565 \mathrm{~g}$ \\
Vitamin mix stock solution & $1.0 \mathrm{~mL}$ \\
Trace elements stock solution & $1.0 \mathrm{~mL}$ \\
\hline
\end{tabular}

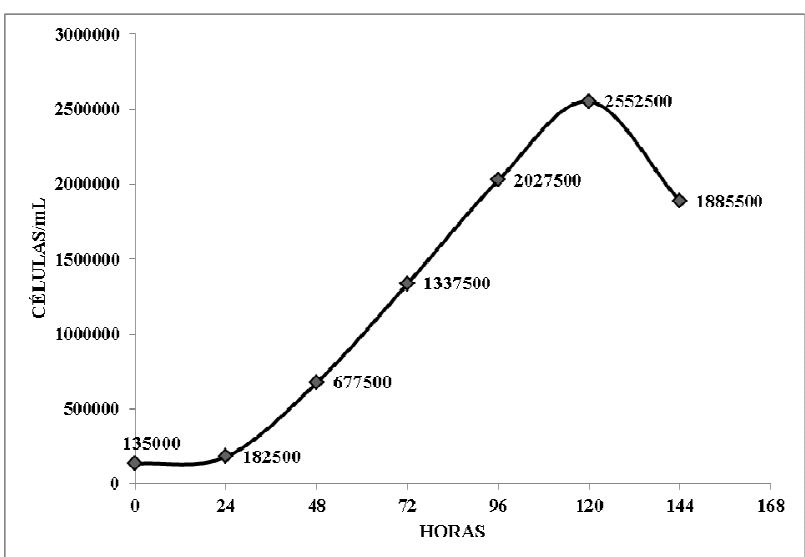

Figure 2. Growth kinetics during $144 \mathrm{~h}$ of Tetraselmis sp.

\section{Microalgal biomass harvest}

The $3000 \mathrm{~mL}$ harvested were withdrawn from the growth chamber, and added to them 925.13 $\mu$ mol of $\mathrm{KAl}(\mathrm{SO} 4)$ to flocculate the biomass. The precipitate retrieved from the flocculation process was subjected to centrifugation for 10 minutes at $3000 \mathrm{rpm}$. The pellet obtained in each harvest was weighed on a Sartorius Analytical scale, model: BL $210 \mathrm{~S}$, with an accuracy of $0.01 \mathrm{mg}$.

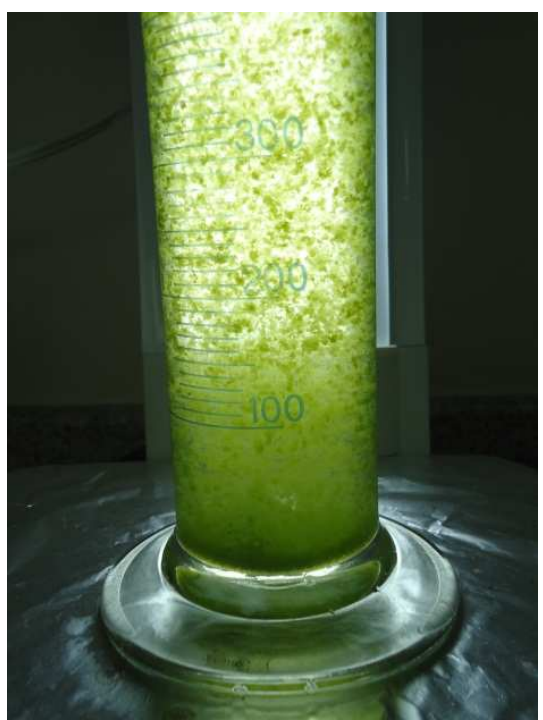

Figure 3. Flocculation of microalgae biomass with $\mathrm{KAl}\left(\mathrm{SO}_{4}\right)$

\section{Biomass obtained}

A total of five harvests was carried out, with a mean value of $12.16 \mathrm{~g}$; this is equivalent to 1.35 $\mathrm{g} / \mathrm{L} / \mathrm{d}$, generating a total mass of $60.8 \mathrm{~g}$ during the massive production period.

Table 2. Biomass obtained in different cultures in continuous cropping of Tetraselmis sp.

\begin{tabular}{lrrrrr}
\hline & \multicolumn{1}{c}{ C 1 } & \multicolumn{1}{c}{ C 2 } & C 3 & C 4 & C 5 \\
\hline Weight (g). & 11.7 & 11.4 & 12.8 & 12.4 & 12.5 \\
Media & 3.9 & 3.8 & 4.26 & 4.13 & 4.16 \\
\hline
\end{tabular}

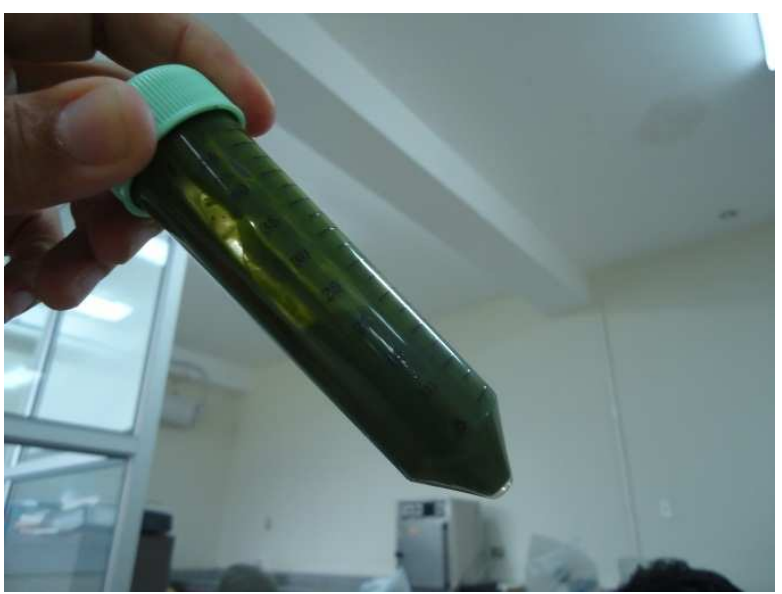

Figure 4. Microalgae biomass obtained. 


\section{Conclusions and Recommendations}

The small-scale reactor of the present study maintained the conditions for continuous culture of Tetraselmis sp. and biomass was harvested periodically without affecting the physiological development of microalgae.

The biomass data obtained agree with work done previously [7]. Response remained within the exponential region. More extended work should reach the stabilization and saturation stage.

The flocculation and centrifugation methods combined gave a total utilization of the biomass obtained.

Future research should evaluate the kinetics of growth of Tetraselmis sp. with culture media formulated with agricultural fertilizers in order to reduce costs. Care should be taken to balance the $\mathrm{N} / \mathrm{P}$ ratio

The need to determine culture response to the supply of $\mathrm{CO}_{2}$ still remains, specifically the effect of concentration and diffusion of the gas in the culture media.

Another important parameter to evaluate is the effect of intensity and characteristics of the applied photosynthetically active radiation

The effect of other culture stressors still remains to be ascertained.

\section{Acknowledgment}

This research was partially supported by a grant from the Agencia Española para la Cooperacion Internacional - AECI (International Cooperation Agency of Spain).

Special thanks to the Faculty of Natural Sciences, University of Guayaquil, the Escuela Superior Politécnica del Litoral and the University of Santiago de Compostela

\section{References}

[1] T. Pillay, "Acuicultura: Principios y Prácticas. Editorial LIMUSA.S.A. $1^{\text {era }}$ Ed. México (1997), pp. 35-55.

[2] R. Abibidi, "Use of probiotic in larval rearing of new candidate species". National Bureau of Fish. Genetic Resources (2003), Vol. 8(2), pp. 1516.
[3] V. Morales, and A. Develotti, "Phytoplankton" PRADEPESCA. UNION EUROPEA Y OLDEPESCA (1990), Vol. 2, pp. 1-21.

[4] R.D. Andrade, R. Torres, E.J. Montes and A.C. Fernández "Obtaining of flour to leave of the cultivation of Chlorella vulgaris and their protein analysis". Temas Agrarios (2007), Vol. 12:(1), pp. 50-57.

[5] L. Gouveia and A.C. Oliveira, "Microalgae as a raw material for biofuels production". J Ind Microbiol Biotechnol (2009), Vol. 36, pp. 269-274.

[6] R. Guillardand J. Ryther,"Studies of marine planktonic diatoms. Cyclotella nana Hustedt and Detonula confervaceae(Cleve)" Gran.Can. J. Microbiol (1962).

[7] J. Santos, y X. Álvarez, "Evaluación del medio de cultivo Guillard modificado F2 para la producción masiva de Tetraselmis sp.como fuente de biocombustible. Laboratorio de Biotecnología y Genética, Facultad de Ciencias Naturales, Universidad de Guayaquil, Guayaquil, Ecuador, (2011). 